\title{
Phenotypic diversity of pea (Pisum sativum L.) varieties and the polyphenols, flavonoids, and antioxidant activity of their seeds
}

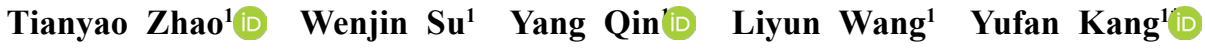 \\ ${ }^{1}$ College of Agronomy, China Agricultural University (CAU), 100193, Beijing, China. E-mail: yfkang@cau.edu.cn. *Corresponding author.
}

ABSTRACT: Pea (Pisum sativum L.) is the fourth leading legume crop in the world, and its demand is increasing. In this study, the morphological characteristics (seed shape, seed surface, seed coat color, hilum color, cotyledon color, 100-seed weight and color values), total phenolic content (TPC), total flavonoid content (TFC), 2,2'-azinobis-(3-ethylbenzthiazoline-6-sulphonate) (ABTS) free radical scavenging capacity and ferric reducing antioxidant power (FRAP) of 75 pea cultivars were investigated. Results showed rich genetic diversity and a wide range of phenolic contents and antioxidant activities. Sixteen varieties enriched with phenolic contents and high antioxidant activities were screened out. A significant correlation was reported among color values, TPC, TFC, ABTS and FRAP. Principal component analysis (PCA) extracted four principal components with a total cumulative contribution of $81.29 \%$. Hierarchical cluster analysis based on the four extracted principal components resulted in a dendrogram dividing the peas into three groups. In addition, dark pea seeds have potential as a functional food in addition to their traditional role in providing dietary protein and fibre. This study provided a scientific basis for the breeding of pea varieties, development of new products and improvement of pea resource utilization.

Key words: pea, phenotypic diversity, flavonoid, antioxidant activity.

Diversidade fenotípica de variedades de ervilha (Pisum sativum L.) e polifenóis, flavonóides e atividade antioxidante de suas sementes

\begin{abstract}
RESUMO: A ervilha (Pisum sativum L.) é a quarta cultura de leguminosas líder no mundo e sua demanda está aumentando. Neste estudo, as características morfológicas (forma da semente, superficie da semente, cor da casca, cor do hilo, cor do cotilédone, peso de 100 sementes e valores de cor), teor fenólico total (TPC), teor de flavonóides totais (TFC), 2,2. A capacidade de eliminação de radicais livres de '-azinobis(3-etilbenzotiazolino-6-sulfonato) (ABTS) e o poder antioxidante redutor de ferro (FRAP) de 75 cultivares de ervilha foram investigados. Os resultados mostraram rica diversidade genética e uma ampla gama de conteúdos fenólicos e atividades antioxidantes. Dezesseis variedades enriquecidas com conteúdo fenólico e alta atividade antioxidante foram descartadas. Uma correlação significativa foi encontrada entre os valores de cores, TPC, TFC, ABTS e FRAP. A análise de componentes principais (PCA) extraiu quatro componentes principais com uma contribuição total acumulada de 81, 29\%. A análise hierárquica de agrupamento foi baseada nos quatro componentes principais extraídos resultou em um dendrograma dividindo as ervilhas em três grupos. Assim, as sementes de ervilha escura têm potencial como alimento funcional, além de seu papel tradicional no fornecimento de proteina e fibra dietética. Este estudo fornece uma base científica para a criação de variedades de ervilha, desenvolvimento de novos produtos e melhoria da utilização de recursos de ervilha.

Palavras-chave: ervilha, diversidade fenotípica, flavonóide, atividade antioxidante.
\end{abstract}

\section{INTRODUCTION}

Pea (Pisum sativum L., $2 \mathrm{n}=2 \mathrm{x}=14$ ) is an annual or perennial herb belonging to the genus Pisum in the leguminosae family, which can be classified into dry peas, green peas and snow peas (THAKUR et al., 2018). It was originated in western Asia, Mediterranean region, Ethiopia, parts of southwest Asia, and the outer Caucasus, and was traditionally cultivated in cold and wet climatic regions, due to their cold resistance, drought resistance, and barren tolerance (SAHA et al., 2018). China has a long history of pea cultivation and is the world's largest pea producer, which plays a decisive role in pea production. Currently, peas are mainly grown in Yunnan, Sichuan, Hubei, Shandong, Xinjiang and Gansu in China (LI et al., 2017). Peas are widely used as a supplement and feed, green manure, grains and 
fresh vegetables (HAGENBLAD et al., 2014) due to their rich nutritional value and healing properties (SUN et al., 2014).

Morphological characteristics are based on the description of individual traits of plants and are the most traditional and intuitive way to detect genetic variation. These characteristics are important in establishing gene pool collections and efficient use of crop germplasm resources (SANTOS et al., 2012). Morphological characteristics are the result of the combination of environment and genetics, including regulatory and structural genes, and their variants revealed their own genetic underpinnings; thus, a change in phenotypic characteristics is a sign of genetic expression (DEAN et al., 1999). Although, some advanced molecular techniques have been used for the improvement of varieties, morphological characteristics are still the most basic tool for evaluating modern breeding. Morphological description has been widely used in plant germplasm identification and classification, breeding material selection and genetic diversity research.

Many researchers have studied the genetic diversity of pea germplasm resources. KENENI et al. (2015) used 12 agronomic traits to analyse the diversity of 148 pea cultivars from Ethiopia and reported that Ethiopian pea landraces had high heredity. With respect to morphology and quality, 271 domestic and foreign pea resources were analysed for genetic diversity, and it was reported that pea germplasm resources had rich genetic variation both within China and internationally (WAN et al., 2017). Analysis of pea genetic diversity under varied environmental conditions is conducive to pea germplasm resource mining and innovation and has played an important role in pea production and breeding.

The sophistication of people's diets and the development of science and technology had increasingly diversified, and the biological activity of plant phenolic compounds has become an important area of research. Phenolic compounds are derivatives of the pentose phosphate, phenylpropanoid and shikimate pathways in plants (RANDHIR et al., 2004), and phenolic acids, flavonoids and tannins are the most important dietary phenolic compounds (KING \& YOUNG, 1999). Phenolic compounds are commonly reported in plants (legumes, vegetables and grains) and are the most abundant secondary metabolites (RAUTER et al., 2005). Legume seeds account for meaningful amounts of protein, starch, dietary fibre, carbohydrates, certain fatty acids and micronutrients (vitamins, trace minerals) (DUEñAS et al., 2015; TORRES et al., 2016). They are also a good source of many bioactive non-nutrient compounds, including phenolic antioxidants (MESSINA, 1999; SCALBERT et al., 2005; GEIL \& ANDERSON, 1994).

As an essential component of the human diet, phenolic compounds play an important role in combating oxidative stress in the human body by maintaining a balance between oxidants and antioxidants (HUNG, 2016). Phenolic compounds are natural antioxidant due to their ability to scavenge free radicals, donate hydrogen atoms, electron, and chelate metal cations (AMAROWICZ et al., 2004). The DPPH, ABTS, and FRAP methods have been widely used to evaluate the antioxidant capacity of seeds, vegetables and fruits (SEGEV et al., 2010; XU et al., 2014; ZHU et al., 2010.).

In response to an increasingly complex market for high-quality and unique food legume products, it is imperative to develop improved food legume varieties. Therefore, the objective of this study was to analyse the morphological characteristics of 75 pea cultivars from 12 regions and two companies and select the varieties with rich genetic diversity to provide a reference for the study of pea germplasm resources. In addition, phenolic contents and antioxidant activity were measured, and high-quality antioxidant varieties were selected to improve the utilization of pea resources and to provide added value to the products. Based on this analysis, we described the correlation among phenotypic traits, phenolic contents, antioxidant activity and color of pea seeds and identify potential genotypes for pea breeders aiming to exploit the most desirable characteristics.

\section{MATERIALS AND METHODS}

\section{Materials}

Pea germplasms were collected from 12 Academies of Agricultural Sciences, China, including Sichuan (SCAAS), Zhangjiakou (ZJKAAS), Qingdao (QDAAS), Xinjiang (XJAAS), Dingxi (DXAAS), Gansu (GSAAS), Qinghai (QHAAS), Beijing (CAAS), Inner Mongolia (IMAAS), Yanjiang (YJAAS), Hubei (HBAAS), and Chongqing (CQAAS), and two company collections (Table 1). Seventy-five pea varieties were obtained, including 20 varieties from QDAAS (the largest collection); 13 and 10 from SCAAS and DXAAS, respectively; 5 each from ZJKAAS and XJAAS; 3 each from GSAAS and CQAAS; 4 from QHAAS; 2 from IMAAS; and 1 each from CAAS, HBAAS and the two companies. All pea varieties were tested from one batch, which were harvested in 2017. 
Table 1 - The name and regional distribution of pea genetic resources for phenotypic diversity analysis.

\begin{tabular}{|c|c|c|c|c|c|}
\hline Sample source & Code & Variety & Sample source & Code & Variety \\
\hline \multirow{13}{*}{ SCAAS } & $\mathrm{P} 1$ & Fengyou 1 & \multirow{5}{*}{ XJAAS } & P39 & Canadian yellow peas \\
\hline & $\mathrm{P} 2$ & Chengwan 268-1 & & $\mathrm{P} 40$ & Canadian linen peas \\
\hline & P3 & Chengwan 7 & & P41 & Canadian peas \\
\hline & $\mathrm{P} 4$ & Chengwan 8 & & P42 & Canadian white peas \\
\hline & P5 & Chengwan 9 & & P43 & Xinjiangxiaobaiwan \\
\hline & P6 & Chengwan 10 & \multirow{10}{*}{ DXAAS } & P44 & Dingwan 1 \\
\hline & P7 & Chengwan 11 & & $\mathrm{P} 45$ & Dingwan 2 \\
\hline & P8 & Wuxudoujian 1 & & P46 & Dingwan 3 \\
\hline & P9 & Wuxudoujian 2 & & P47 & Dingwan 4 \\
\hline & $\mathrm{P} 10$ & Shijiadacaiwan 1 & & P48 & Dingwan 5 \\
\hline & $\mathrm{P} 11$ & Shijiadacaiwan 6 & & P49 & Dingwan 6 \\
\hline & $\mathrm{P} 12$ & Shijiatiancuiwan 3 & & P50 & Dingwan 7 \\
\hline & $\mathrm{P} 13$ & Zhushawan & & P51 & Dingwan 8 \\
\hline \multirow{5}{*}{ ZJKAAS } & $\mathrm{P} 14$ & ZDW & & P52 & $9618-2$ \\
\hline & $\mathrm{P} 15$ & Qianjin 1 & & P53 & 20012 \\
\hline & P16 & Zhangwan 2 & \multirow{3}{*}{ GSAAS } & P54 & Longwan 1 \\
\hline & P17 & Bawam 1 & & P55 & Longwan 3 \\
\hline & $\mathrm{P} 18$ & Bawan 6 & & P56 & New Zealand 3 \\
\hline \multirow{20}{*}{ QDAAS } & P19 & 16WDS002 & \multirow{4}{*}{ QHAAS } & P57 & Caoyuan 23 \\
\hline & $\mathrm{P} 20$ & 16WDS003 & & P58 & Caoyuan 24 \\
\hline & $\mathrm{P} 21$ & 16WDS004 & & P59 & Caoyuan 28 \\
\hline & $\mathrm{P} 22$ & 16WDS005 & & $\mathrm{P} 60$ & Caoyuan 224 \\
\hline & $\mathrm{P} 23$ & 16WDS006 & CAAS & P61 & Zhongwan 6 \\
\hline & $\mathrm{P} 24$ & 16WDS007 & \multirow{2}{*}{ IMAAS } & P62 & Baiwandou \\
\hline & $\mathrm{P} 25$ & 16WDS009 & & P63 & Qingwandou \\
\hline & P26 & 16WDS010 & \multirow{6}{*}{ YJAAS } & P64 & Suwan 2 \\
\hline & $\mathrm{P} 27$ & 16WDS012 & & P65 & Suwan 3 \\
\hline & $\mathrm{P} 28$ & 16WDS013 & & P66 & Suwan 4 \\
\hline & P29 & 16WDS015 & & P67 & Suwan 12 \\
\hline & P30 & 16WDS016 & & P68 & Taiwanxiaobaihua \\
\hline & P31 & 16WDS017 & & P69 & Haimenbaiyuwan \\
\hline & P32 & 16WDS018 & HBAAS & $\mathrm{P} 70$ & Ewan 3 \\
\hline & P33 & 16WDS019 & \multirow{3}{*}{ CQAAS } & P71 & Suoshadabaiwan \\
\hline & P34 & 16WDS020 & & $\mathrm{P} 72$ & Wushanchangshouren \\
\hline & P35 & 16WDS021 & & P73 & Wushanzihuawan \\
\hline & P36 & 16WDS022 & New Rural & P74 & Xinnongcun \\
\hline & P37 & 16WDS023 & Green Valley & P75 & Lvshangu \\
\hline & P38 & 16WDS024 & & & \\
\hline
\end{tabular}

\section{Determination of color value}

The chromaticity of the different pea seeds was measured for $L^{*}, a^{*}$ and $b^{*}$ using a KONICA MINOLTA CM-700d colorimeter (Konica Minolta Co., Ltd., Tokyo, Japan) as described by XU et al. (2007).

\section{Morphological characteristics}

The unified standards for pea seed observation and data on morphological traits were adopted from ZONG et al. (2005). In total, five qualitative characters (seed shape, seed surface, seed coat color, hilum color, cotyledon color) were analysed in accordance with the character value of the code after digital analysis. The character grading code is presented in table 2 . For the 100 -grain weight of classification code 10: $1<\mathrm{X}-2 \delta, 10 \geq \mathrm{X}+2 \delta$, where the mean of every $0.5 \delta$ is used for the first expression, $\mathrm{X}$ indicates the average, and $\delta$ indicates the standard deviation. Seventy-five varieties were planted in their source regions (Table 1). 
Chemical analyses

Determination of total phenolic (TPC) and total flavonoid (TFC) contents

The extraction of pea phenolic compounds was modified slightly from the methods of previous authors (SHEM-TOV et al., 2012). The samples were ground into a powder, after which a $0.5 \mathrm{~g}$ portion of powder was extracted and added to $5 \mathrm{~mL}$ of acetone/water/acetic acid (70:29.5:0.5, v/v/v) solution in an ultrasonic bath for $20 \mathrm{~min}$. Samples were then centrifuged for $10 \mathrm{~min}$ to extract the supernatant to determine the TPC and TFC and for ABTS and FRAP analysis. The extraction procedure was carried out in triplicate.

TPC was measured using the FolinCiocalteu assay (LIU et al., 2016). The standard curve was expressed as mg of gallic acid equivalent per $\mathrm{g}$ of dry weight (mg GAE/g DW). TFC was analysed using the aluminium chloride method (PAJAK et al., 2014). Results were expressed as mg of rutin equivalents per $\mathrm{g}$ of dry sample (mg RUT/g DW). Each sample was repeated three times.

The ABTS free radical scavenging capacity was determined according to method described by WANG et al. (2015). The results were expressed in terms of Trolox ( $\mu \mathrm{M}$ TE/g DW) equivalent per $g$ of dry sample. The ferric reducing antioxidant power (FRAP) was measured as previously described by MÜLLER et al. (2011). The standard curve was measured with $\mathrm{FeSO}_{4}$, and the results were expressed as $\mathrm{mM} \mathrm{Fe}^{2+}$ per $\mathrm{g}$ of dry sample $\left(\mathrm{mM} \mathrm{Fe}^{2+} / \mathrm{g} \mathrm{DW}\right)$. Each sample was repeated three times.

\section{Statistical analysis}

The Shannon-Wiener diversity index (H') (MARTíNEZ et al., 2017) for morphological characters was used to measure all varieties. It was calculated according to the equation 1 :

$$
H^{\prime}=-\sum_{i=1}^{K} P_{i} \operatorname{In} P_{i}
$$

Where $p_{i}$ is the proportion of individuals in the each class of k-class trait, and $\mathrm{k}$ is the number of phenotypic classes for a given trait. This index is a measure of phenotypic diversity based on frequency data. (JIAN et al., 2017).

All the original data were transformed into standardized data to eliminate the difference in the variance of each character. Pearson's correlation test (XU et al., 2009) was used to determine the correlation among variables. Principal component analysis (PCA) was performed to generate a cluster diagram (AIL-SHTAYEH, 2017). The eigenvalue and contribution percentage of each principal component axis were calculated using the correlation matrix among morphological characters, chromatic value, TPC, TFC, ABTS and FRAP for all 75 varieties. Cluster analysis was performed using scores of the first four principal components to group the varieties. All computations were carried out using SigmaPlot 12.5 and SPSS 20.0.

\section{RESULTS}

\section{Variation in morphological traits \\ The frequency distribution for the five} qualitative traits is presented in figure 1. In the collection, seed coat color was characterized by five descriptors, the cream was dominant reaching $45.3 \%$ of all collection, followed by the green, brown with stripes or spots and brown, the purple-dark was rare (Figure 1 (a)). The order of hilum color was yellow hilum $>$ greyish $>$ brown $>$ black (Figure 1 (b)). Four descriptors were observed for cotyledon color to differentiate pea varieties. Results showed that cream cotyledons accounted for 33 varieties, fifteen varieties had yellowish green, 14 varieties had green and 13 varieties had orange cotyledon color (Figure 1 (c)). The distribution of three seed surface was relatively uniform, with mostly dimpled surface, followed by smooth and wrinkled (Figure 1 (d)). Additionally, three seed shapes (spherical, oval-elongated, and

Table 2 - Classification of the 5 qualitative traits of interest of 75 pea germplasm resources.

\begin{tabular}{lc}
\hline Traits & Classification code \\
\hline Seed shape & 1 Spherical, 2 Oval-elongated, 3 Square shaped \\
Seed surface & 1 Smooth, 2 Dimpled, 3 Wrinkled \\
Seed coat color & 1 Cream, 2 Pink, 3 Green, 4 Brown, 5 Brown with stripes or spots, 6 Purple-dark \\
Hilum color & 1 Yellow, 2 Greyish, 3 Brown, 4 Black \\
Cotyledon color & 1 Cream, 2 Orange, 3 Pink, 4 Yellowish green, 5 Green \\
\hline
\end{tabular}

Ciência Rural, v.50, n.5, 2020. 


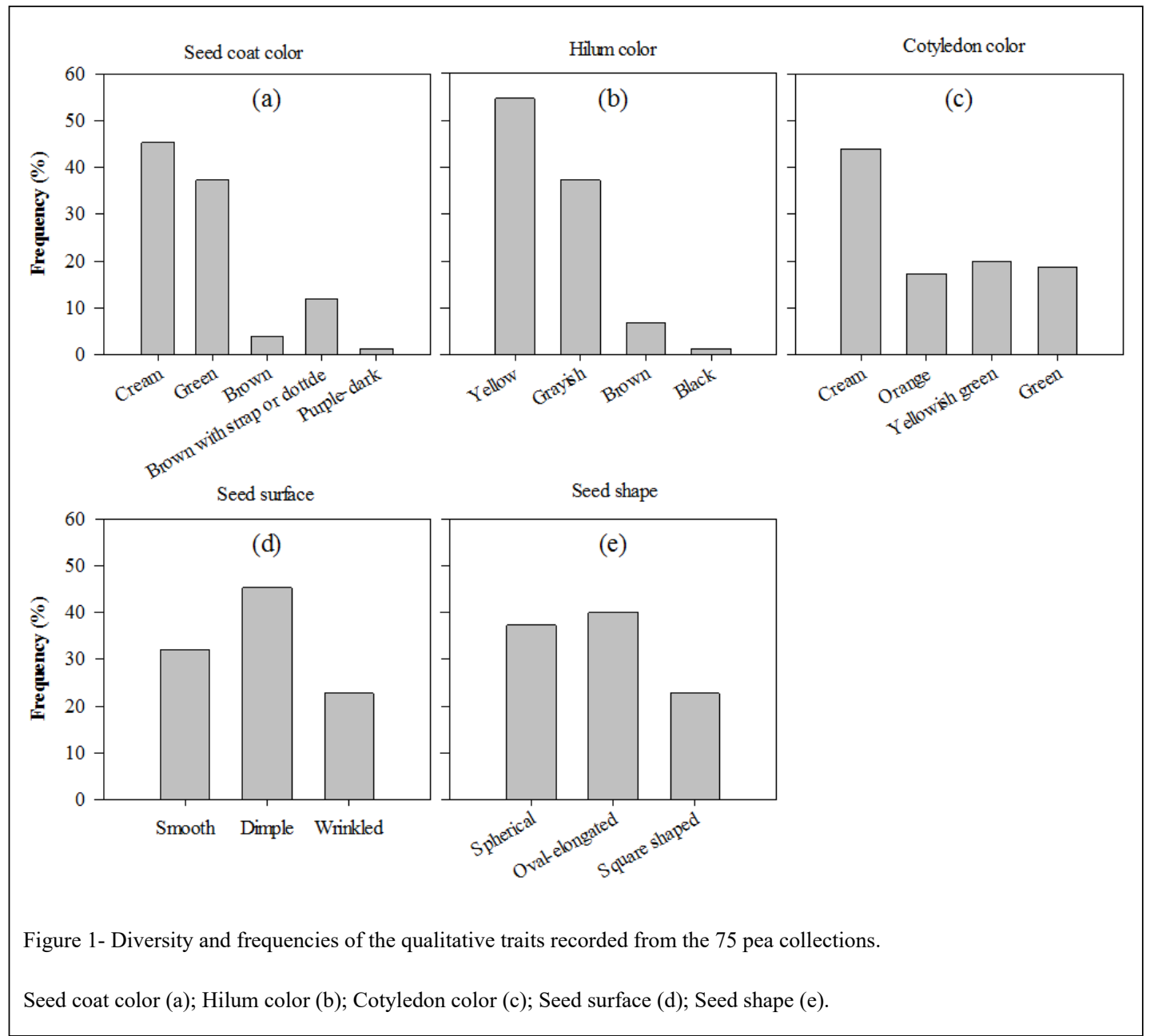

square) were observed, accounting for $37.3 \%, 40.0 \%$ and $22.7 \%$, respectively (Figure $1(\mathrm{e})$ ).

Hundred-mature-seed weight (100-SW) of each cultivar mainly ranged from $19.1-21.5$ $\mathrm{g}$, accounting for $21.3 \%$ of the tested cultivars. A 100-SW less than $11.7 \mathrm{~g}$ or more than $31.4 \mathrm{~g}$ each accounted for $1.3 \%$ of the total (Figure 2).

For each quantitative trait and 100SW evaluated, the descriptive statistics, including mean, maximum, minimum, coefficient of variation $(\mathrm{CV})$ and $\mathrm{H}^{\prime}$ are summarized in table 3. Among the characteristics, the ranking of $\mathrm{CV}$ was as follows: cotyledon color $>$ seed coat color $>$ hilum color $>$ seed shape $>$ seed surface. Overall, the qualitative traits showed considerably high $\mathrm{H}^{\prime}$, ranging from 0.94 to 1.30 . The ranking of $\mathrm{H}^{\prime}$ was as follows: cotyledon color $>$ seed coat color $>$ seed shape $>$ seed surface $>$ hilum color. The $100-\mathrm{SW}$ of pea ranged from
35.28-11.52 g. The lowest was for 16WDS005, and the highest was for New Zealand 3. Besides, the 100SW exhibited high diversity, with an H' of 2.06.

Statistical analysis of the quality traits and quantitative trait data showed that the pea germplasm resources had abundant genetic variation. The variety of phenotypic traits of the tested resources was quite different and had greater room for improvement, which provided an excellent germplasm base for the breeding of pea varieties.

\section{Determination of color value}

The $L^{*}, a^{*}$ and $b^{*}$ values and chroma (saturation) for pea seeds are presented in attachment. $L^{*}$ values ranged from 19.47 to 62.98 ; the greatest variety of $L^{*}$ was reported in Caoyuan 24, and the least variety was found in 16WDS018. The range of $a^{*}$ values was -0.24 to 8.73 ; the greatest variety

Ciência Rural, v.50, n.5, 2020. 


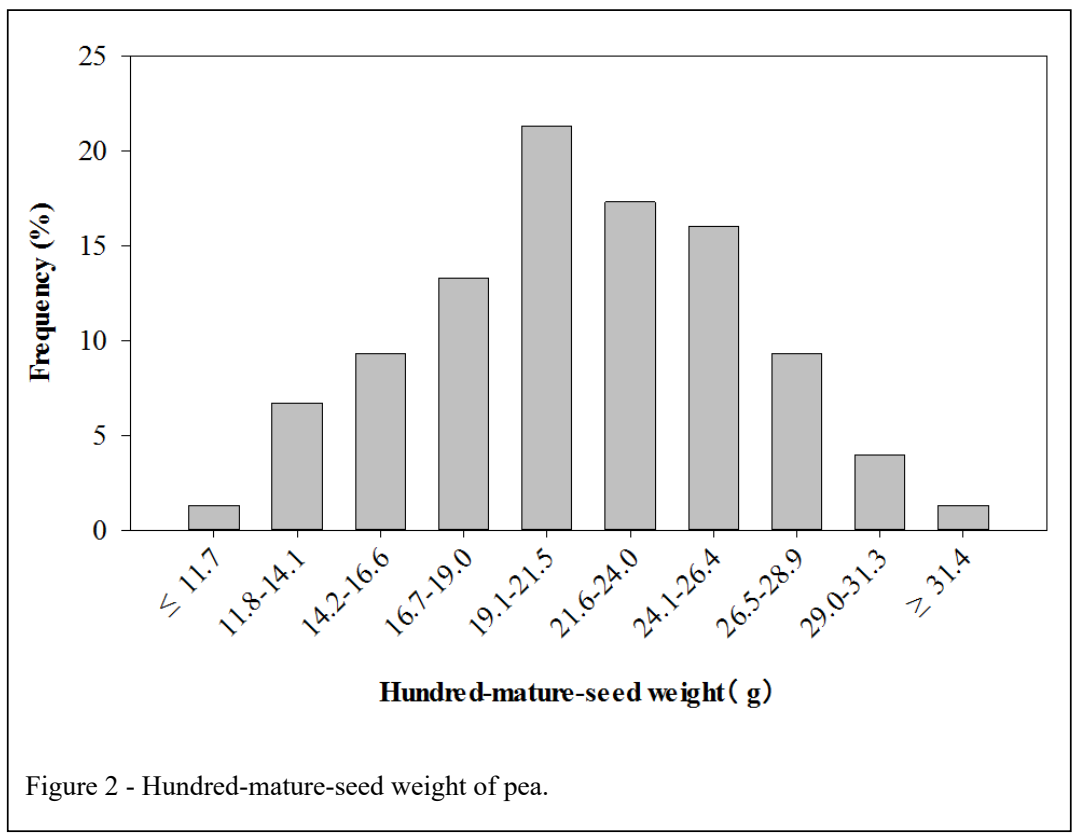

was reported in Zhushawan, and the least variety was found in 16WDS003. The $b^{*}$ values ranged from -0.55 to 23.93, with the greatest variety in Chengwan 10 and the least variety in 16WDS018. The color of the pea seed observed with the naked eye was consistent with the results of this measurement, indicating the reliability of naked-eye observation.

Determination of the total phenolic content (TPC) and total flavonoid content (TFC)

After investigating the basic morphological characteristics of pea seeds and their rich genetic diversity, we studied the content and antioxidant properties of phenolic compounds in order to extract more potential varieties and develop functional products.
Figure 3(a) shows that the TPC of 75 pea varieties ranged from 0.27 to $1.95 \mathrm{mg} \mathrm{GAE} / \mathrm{g} \mathrm{DW}$. The pea varieties with the lowest and highest TPC were 16WDS017 and 16WDS018, respectively. Twenty-two varieties had a higher-than-average TPC (0.54 mg GAE/g DW).

The TFC in this same sample ranged from 0.53 to $5.08 \mathrm{mg}$ RUT/g DW (Figure 3(b)). The varieties with the lowest and highest TFC were 16WDS017 and 16WDS021, respectively. Among them, 29 varieties had a higher-than-average TFC (0.98 mg RUT/g DW).

\section{Determination of antioxidant activity}

The ABTS free radical scavenging capacity ranged from 3.04 to $22.27 \mu \mathrm{M}$ TE/g (Figure

Table 3 - The variation parameter and diversity index of the qualitative traits and 100-SW (g).

\begin{tabular}{lcccccc}
\hline Traits & Min. & Max. & Mean & SD & CV $(\%)$ & H' \\
\hline Seed shape & 1 & 3 & 1.85 & 0.77 & 41.41 & 1.07 \\
Seed surface & 1 & 3 & 1.91 & 0.74 & 38.64 & 1.06 \\
Seed coat color & 1 & 6 & 2.41 & 1.46 & 60.66 & 4.17 \\
Hilum color & 1 & 4 & 1.55 & 0.68 & 4.13 \\
Cotyledon color & 1 & 5 & 2.52 & 1.64 & 65.04 & 22.76 \\
100-SW & 11.52 & 35.28 & 21.44 & 4.88 & 2.06 \\
\hline
\end{tabular}

CV, Coefficient of variation ; H', Shannon-Wiener diversity index ; 100-SW, Hundred-mature-seed weight. 


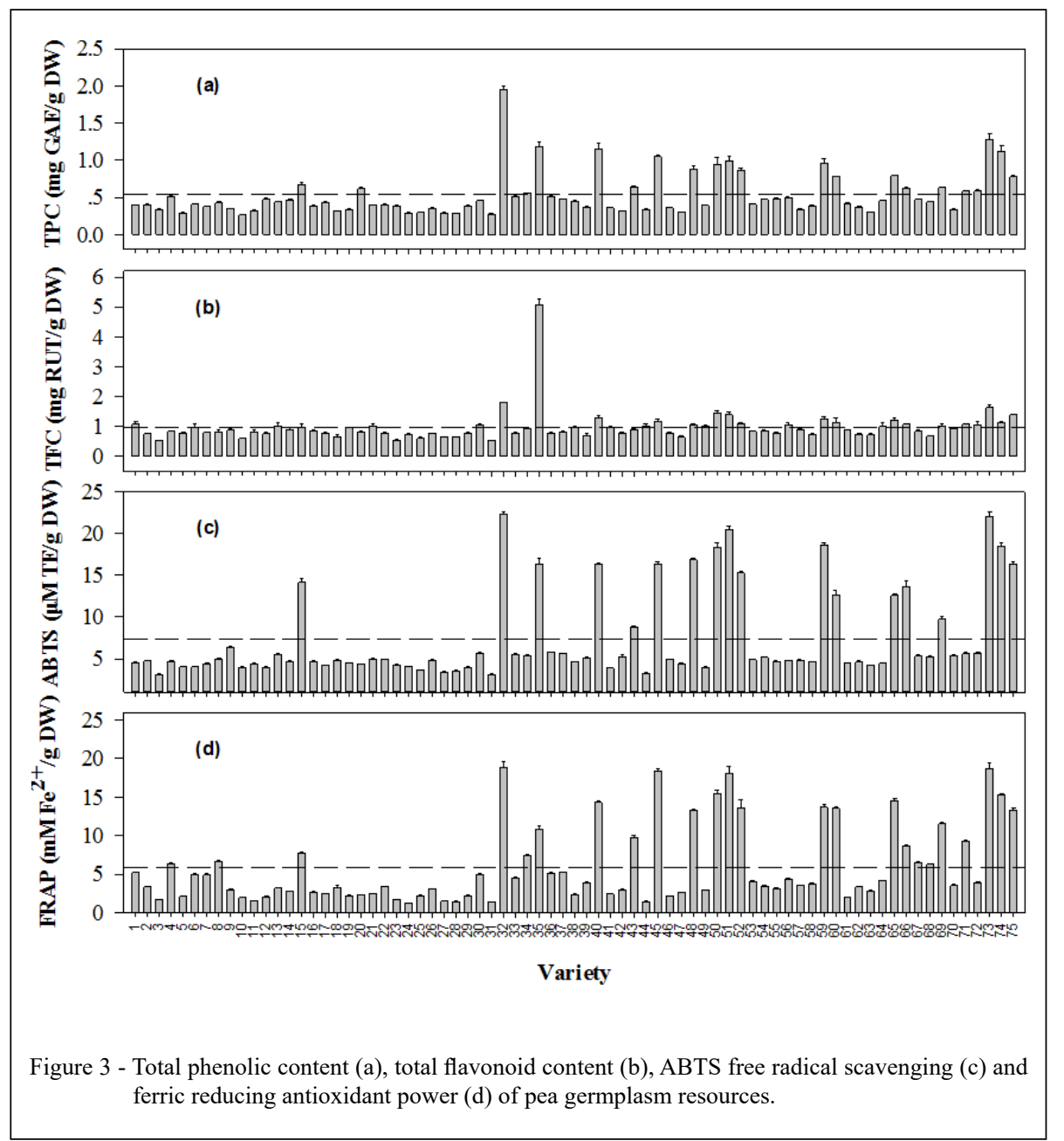

$3(\mathrm{c}))$. The strongest variety was $16 \mathrm{WDS} 018$, and the weakest was 16 WDS017. Eighteen varieties had a higher-than-average ABTS free radical scavenging ability $(7.38 \mu \mathrm{M} \mathrm{TE} / \mathrm{g})$.

The FRAP of 75 pea varieties ranged from 1.24 to $18.87 \mathrm{mM} \mathrm{Fe}^{2+} / \mathrm{g}$ DW (Figure 3(d)). The varieties with the weakest and strongest antioxidant activity were 16WDS007 and 16WDS018, respectively. Twenty-four varieties had a higher-than-average ferrous reduction capacity $\left(5.95 \mathrm{mM} \mathrm{Fe}^{2+} \mathrm{g} \mathrm{DW}\right)$.

In total, 16 varieties were higher than the average of phenolic contents and antioxidant activity, including Qianjing1, 16WDS018, 16WDS021, Canadian linen peas, Dingwan2, Dingwan5, Dingwan7, Dingwan8, 9618-2, Caoyuan28, Suwan3, Sunwan4, Haimenbaiyuwan, Wushanzihuawan and two company varieties, which enriched with phenolic contents and antioxidant activities.

\section{Multivariate correlation analysis}

Correlation results of morphological traits, color values, TPC, TFC and antioxidant activity are provided in table 4. First, the phenolic compound contents and antioxidant activities were significantly correlated with morphological characteristics (except for seed shape, seed surface and 100-SW), such as TPC and seed coat color ( $\mathrm{r}=0.641, P<0.01)$, hilum color $(\mathrm{r}=0.339, P<0.01)$, and cotyledon color $(\mathrm{r}=-$ $0.263, P<0.05)$. In addition, TFC was positively correlated with seed coat color $(\mathrm{r}=0.287, P<0.05)$. ABTS was significantly correlated with seed coat color $(\mathrm{r}=0.663, P<0.01)$, hilum color $(\mathrm{r}=0.429$, $P<0.01)$ and cotyledon color $(\mathrm{r}=-0.357, P<0.01)$. The FRAP was significantly correlated with seed coat color $(\mathrm{r}=0.578, P<0.01)$, hilum color $(\mathrm{r}=0.371$, $P<0.01)$, and cotyledon color $(\mathrm{r}=-0.397, P<0.01)$. We can initially screen for high phenolic contents 
Table 4 - Correlation among morphological traits, TPC, TFC and antioxidant activity in pea germplasm resources.

\begin{tabular}{|c|c|c|c|c|c|c|c|c|c|c|c|c|c|}
\hline & $\mathrm{X} 1$ & $\mathrm{X} 2$ & $\mathrm{X} 3$ & $\mathrm{X} 4$ & X5 & X6 & X7 & X8 & X9 & $\mathrm{X} 10$ & $\mathrm{X} 11$ & $\mathrm{X} 12$ & $\mathrm{X} 13$ \\
\hline $\mathrm{X} 1$ & & -0.142 & -0.172 & 0.01 & -0.015 & 0.021 & 0.06 & -0.057 & 0.143 & -0.026 & 0.056 & 0.110 & -0.224 \\
\hline $\mathrm{X} 2$ & & & $0.594^{* *}$ & $0.915^{* *}$ & $0.896^{* *}$ & $-0.734^{* *}$ & 0.197 & $-0.674^{* *}$ & 0.158 & 0.022 & $0.641^{* *}$ & $0.339^{* *}$ & $-0.263^{*}$ \\
\hline $\mathrm{X} 3$ & & & & $0.542^{* *}$ & $0.468^{* *}$ & $-0.354^{* *}$ & 0.155 & -0.187 & 0.202 & 0.085 & $0.287^{*}$ & 0.180 & 0.013 \\
\hline $\mathrm{X} 4$ & & & & & $0.939^{* *}$ & $-0.727^{* *}$ & $0.319^{* *}$ & $-0.612^{* *}$ & 0.139 & -0.048 & $0.663^{* *}$ & $0.429^{* *}$ & $-0.357^{* *}$ \\
\hline $\mathrm{X} 5$ & & & & & & $-0.642^{* *}$ & $0.331^{* *}$ & $-0.545^{* *}$ & 0.112 & -0.084 & $0.578^{* *}$ & $0.371^{* *}$ & $-0.397^{* *}$ \\
\hline X6 & & & & & & & -0.021 & $0.699^{* *}$ & $-0.312^{* *}$ & $-0.265^{*}$ & $-0.787^{* *}$ & $-0.351^{* *}$ & 0.060 \\
\hline X7 & & & & & & & & 0.121 & $-0.288^{*}$ & $-0.375^{* *}$ & $-0.331^{* *}$ & $0.309^{* *}$ & $-0.781^{* *}$ \\
\hline $\mathrm{X} 8$ & & & & & & & & & -0.033 & 0.090 & $-0.741^{* *}$ & $-0.269^{*}$ & -0.008 \\
\hline X9 & & & & & & & & & & $0.740^{* *}$ & $0.345^{* *}$ & 0.155 & 0.180 \\
\hline $\mathrm{X} 10$ & & & & & & & & & & & $0.299^{* *}$ & -0.005 & $0.342^{* *}$ \\
\hline X11 & & & & & & & & & & & & $0.312^{* *}$ & $0.242^{*}$ \\
\hline $\mathrm{X} 12$ & & & & & & & & & & & & & $-0.245^{*}$ \\
\hline X13 & & & & & & & & & & & & & \\
\hline
\end{tabular}

X1: 100-seed weight (g); X2: Total phenolic content (mg GAE/g DW); X3: Total flavonoid content (mg RUT/g DW); X4: ABTS free radical scavenging activity $(\mu \mathrm{M} \mathrm{TE} / \mathrm{g} \mathrm{DW}) ; \mathrm{X} 5$ : Ferric reducing antioxidant power $\left(\mathrm{mM} \mathrm{Fe}^{2+} / \mathrm{g} \mathrm{DW}\right) ; \mathrm{X} 6: L^{*} ; \mathrm{X} 7: a^{*} ; \mathrm{X} 8: b^{*} ; \mathrm{X} 9$ : Seed shape; X10: Seed surface; X11: Seed coat color; X12: Hilum color; X13: Cotyledon color ${ }^{*}$ and ${ }^{* *}$ indicate significance at $5 \%$ and $1 \%$ levels, respectively.

and antioxidant activity of pea varieties through the morphological traits.

The correlation among phenolic contents, antioxidant properties and seed coat color was the strongest; therefore, we analysed this correlation with color values. Results showed that TPC was related to $L^{*}(\mathrm{r}=-0.734, P<0.01)$ and $b^{*}(\mathrm{r}=-0.674, P<0.01)$; TFC was significantly negatively correlated with $L^{*}(\mathrm{r}=-$ $0.354, P<0.01$ ). A significant negative correlation was reported between ABTS and $L^{*}(\mathrm{r}=-0.730, P<0.01), a^{*}$ $(\mathrm{r}=0.302, P<0.01)$, and $b^{*}(\mathrm{r}=-0.612, P<0.01)$. FRAP was significantly correlated with $L^{*}(\mathrm{r}=-0.642, P<0.01)$ and $b^{*}(\mathrm{r}=-0.545, P<0.01)$. Thus, dark-colored seeds had higher TPC, TFC, ABTS free radical scavenging power and FRAP than light-colored seeds.

Significantly high linear correlation coefficients were reported among TPC, TFC, ABTS and FRAP as seen in the scatter plot (Figure 4). The Figure 4(a) shows that the TPC of pea seeds had a significant positive correlation with ABTS $\left(\mathrm{r}_{1}=0.832, P<0.01\right)$ and FRAP $\left(\mathrm{r}_{2}=0.808, P<0.01\right)$. The Figure 4(b) shows that TPC and TFC had a strong correlation $(\mathrm{r}=0.683, P<0.01)$. The TFC was significantly positively correlated with ABTS free radical scavenging power $\left(\mathrm{r}_{1}=0.647, P<0.01\right)$ and FRAP $\left(\mathrm{r}_{2}=0.642, P<0.01\right)$ (Figure $\left.4(\mathrm{c})\right)$. The ABTS and FRAP had a strong positive correlation $(\mathrm{r}=0.890$, $P<0.01$ ) (Figure 4(d)).
In general, polyphenol contents and antioxidant activity of pea seeds had a high linear correlation, which indicated that the phenolic compounds deactivate the free radicals or convert them into stable compounds (AGOSTINIC-COSTA et al., 2015). Furthermore, significant correlations were reported between seed color parameters and TPC, TFC, and antioxidant activity. In addition, we concluded that dark (brown, brown with stripes or spots, purple-dark) seeds are a good source of bioactive materials. It is important to legume breeders to have easy-to-use markers for functional foodrelated qualities.

\section{Principal component analysis (PCA)}

Because traits were interrelated, PCA was conducted to investigate the impact of individual traits. The significance level as determined by a chi-square test was 0.000 (less than 0.01 ), which indicated that there was a high correlation among the indicators, and that the data were thus suitable for PCA analysis. The first four principal components contributed $81.29 \%$ of the variability among the varieties. Percentages of variation explained by the first four components were $39.93 \%, 21.02 \%, 10.85 \%$ and $9.49 \%$ (Table 5).

For each principal component, a number of traits contributed to the total variation. The PC1 was 

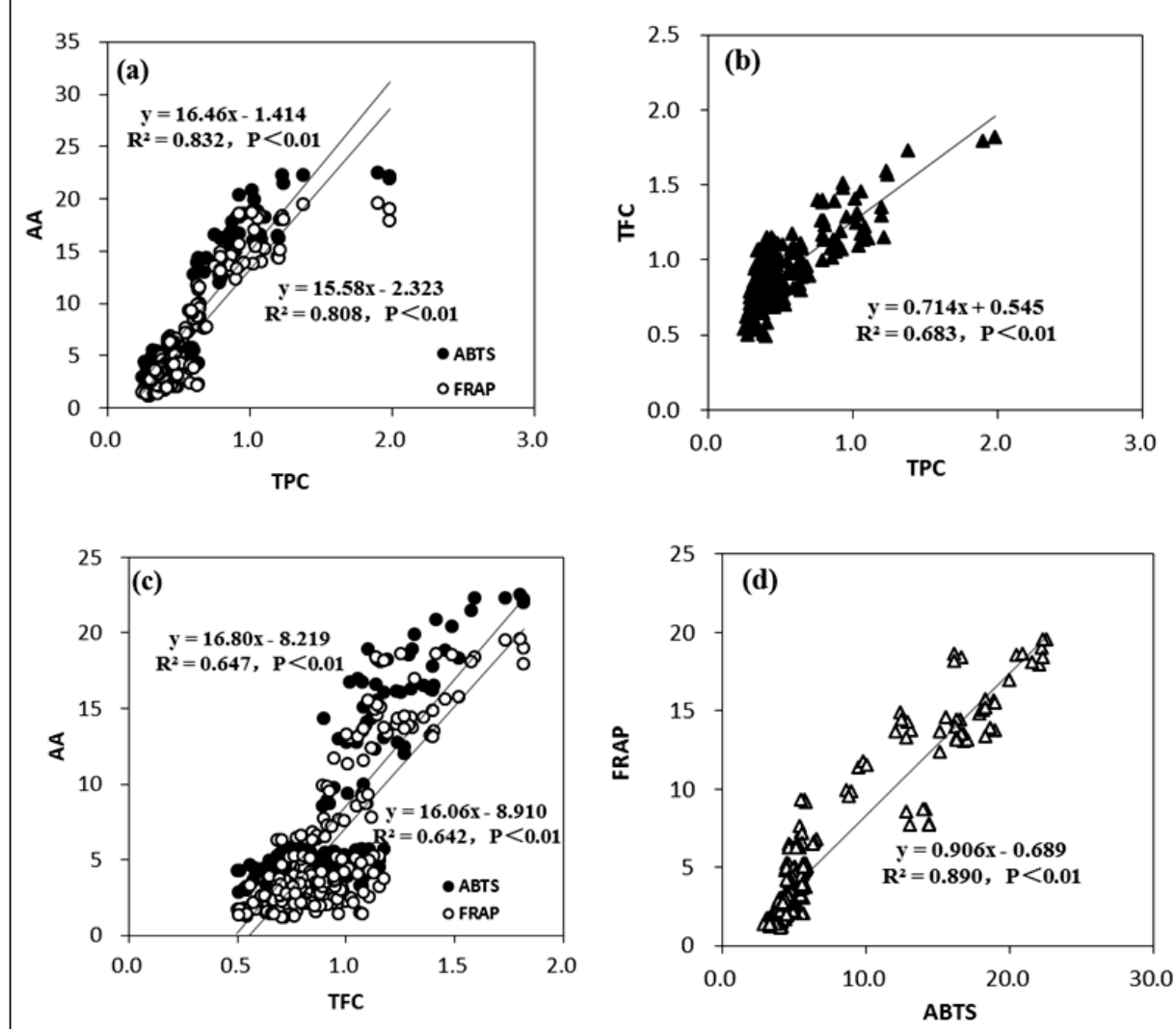

Figure 4 - Correlation coefficients among TPC, TFC and antioxidant activity of 75 pea germplasm.

related to traits including TPC, ABTS free radical scavenging ability, FRAP, $L^{*}, b^{*}$, seed coat color and hilum color. The PC2 was more related to traits including $a^{*}$, seed surface, and cotyledon color. The PC3 was related to seed shape. The 100-SW and TFC played a major role in PC4.

Distribution of 75 pea varieties and the scores of the first and second principal components are shown in Figure 5. The pea varieties could be divided into three clusters. According to these components, 30 varieties with yellow seed coat color were grouped into Cluster I. Cluster II included 10 varieties, which had a dark seed coat color and the highest phenolic contents and antioxidant activity. Lastly, 31 varieties with lower phenolic contents and antioxidant activity and a green seed coat color were clustered into Cluster III.

\section{Clustering analysis}

Based on the first four principal components, 75 pea varieties were clustered by Euclidean genetic distances. The taxonomic distance ranged from 0-25. The dendrogram divided the collected varieties into three major clusters (Clusters I, II, and III) (Figure 6). Cluster I contained 31 varieties with yellow seed coat color. Thirty varieties with green seed coat color and lower phenolic content and antioxidant activity comprised Cluster II. Fourteen varieties with dark seed coat color (brown, brown with stripes or spots, purple-dark) and with the highest phenolic content and antioxidant activity clustered into Cluster III.

\section{DISCUSSION}

The evaluation and description of varieties with one or more desirable traits are the pre-requisites for breeding and processing strategies. The present analysis of the morphological traits of pea varieties revealed significant variation. Results showed that 5 quality traits had CVs ranging from 0.39 to 0.65 , and the genetic diversity was from 0.94 to 1.30 . Among them, the variation and the genetic diversity 
Table 5 - Contribution percentage and major characters associated with the first four principal components of 75 pea varieties and their eigenvectors.

\begin{tabular}{|c|c|c|c|c|}
\hline $\mathrm{X}$ loadings & $\mathrm{PC}-1$ & $\mathrm{PC}-2$ & $\mathrm{PC}-3$ & $\mathrm{PC}-4$ \\
\hline Explained proportion of variation (\%) & 39.93 & 21.02 & 10.85 & 9.49 \\
\hline Cumulative proportion of variation (\%) & 39.93 & 60.95 & 71.81 & 81.29 \\
\hline Traits & \multicolumn{4}{|c|}{ 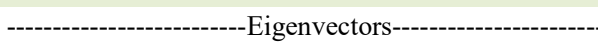 } \\
\hline 100-Seed weight & -0.004 & -0.085 & 0.502 & -0.695 \\
\hline Total phenolic content & 0.939 & -0.086 & -0.118 & 0.160 \\
\hline Total flavonoid content & 0.556 & 0.008 & -0.003 & 0.587 \\
\hline ABTS free radical scavenging activity & 0.949 & -0.190 & -0.007 & 0.045 \\
\hline Ferric reducing antioxidant power & 0.895 & -0.243 & -0.013 & 0.068 \\
\hline$L^{*}$ & -0.857 & -0.216 & 0.005 & 0.094 \\
\hline$a^{*}$ & 0.164 & -0.859 & 0.303 & 0.182 \\
\hline$b^{*}$ & -0.740 & -0.126 & 0.359 & 0.406 \\
\hline Seed shape & 0.265 & 0.611 & 0.636 & 0.140 \\
\hline Seed surface & 0.095 & 0.731 & 0.503 & 0.231 \\
\hline Seed coat color & 0.787 & 0.474 & -0.139 & -0.256 \\
\hline Hilum color & 0.490 & -0.174 & 0.333 & -0.156 \\
\hline Cotyledon color & -0.227 & 0.812 & -0.368 & 0.053 \\
\hline
\end{tabular}

of cotyledon color and seed coat color were more abundant, which was in agreement with previous results (UPADHYAYA et al., 2013). Similarly, 100SW exhibited a high $\mathrm{H}^{\prime}$ and rich genetic variation. The 75 studied pea varieties have extensive genetic diversity related to ecological conditions, climatic conditions, geographical distribution, management measures, and heredity of resources (HOECK et al., 2000). Making full use of pea germplasm resources can lay the foundation for the improvement and breeding of improved varieties.

Many researchers have reported that flavonoids have several important biological activities, such as anti-photo aging, anti-allergenic, anti-inflammatory and cardioprotective effects (LEONARDO \& DORÉ 2011; VAJDY, 2011; WOOD et al., 2004). Furthermore, the flavonoids, which is considered the main source of antioxidant activity in plants (DECKER, 1997; AMAROWICZ et al., 2000; TROSZÝ́SKA \& CISKA 2002), was mainly located in these varieties. This result was in accordance with other studies (DUENÃS et al., 2006; KIM et al., 2012; BAI et al., 2017). Therefore, peas could be used as a natural source of antioxidants to replace the use of synthetic antioxidants in foods. Results showed that the TFC of 16WDS021 was significantly higher than in the other pea varieties; high-performance liquid chromatography (HPLC) could be used to assess the qualitative and quantitative characteristics of the flavonoids in this variety in the future (MEENU et al., 2016; FERRERES et al., 2017).

The color value, TPC, TFC, ABTS and FRAP showed wide variability within the 75 pea varieties, which depended on many factors, such as degree of maturity at harvest and environmental conditions (ZADERNOWSKI et al., 2005). The lowest and highest phenolic contents and antioxidant activity of the 75 pea varieties were all reported in the varieties from Qingdao Academy of Agricultural Sciences. The phenolic contents and antioxidant activity of the pea varieties in the same area were different, which may be related to environmental and genetic factors, such as cultivar, cultivation year, and harvest time (PÉREZ-BALIBREA et al., 2011).

Results obtained using Pearson correlation showed a significant linear correlation between TPC and TFC and between ABTS and FRAP, which were in agreement with previous results (ZHAO et al., 2014; YAO et al., 2012). The TPC and TFC of the pea seeds were strongly correlated with antioxidant activity, which could have possible beneficial effects for human health. Many studies (OU et al., 2002) reported that not only did the total content of polyphenolic compounds play an important role in antioxidant activity but also the type of phenolic compounds was essential. RICE-EVANS et al. (1996) showed the relationship between the antioxidant activity of flavones and their chemical 


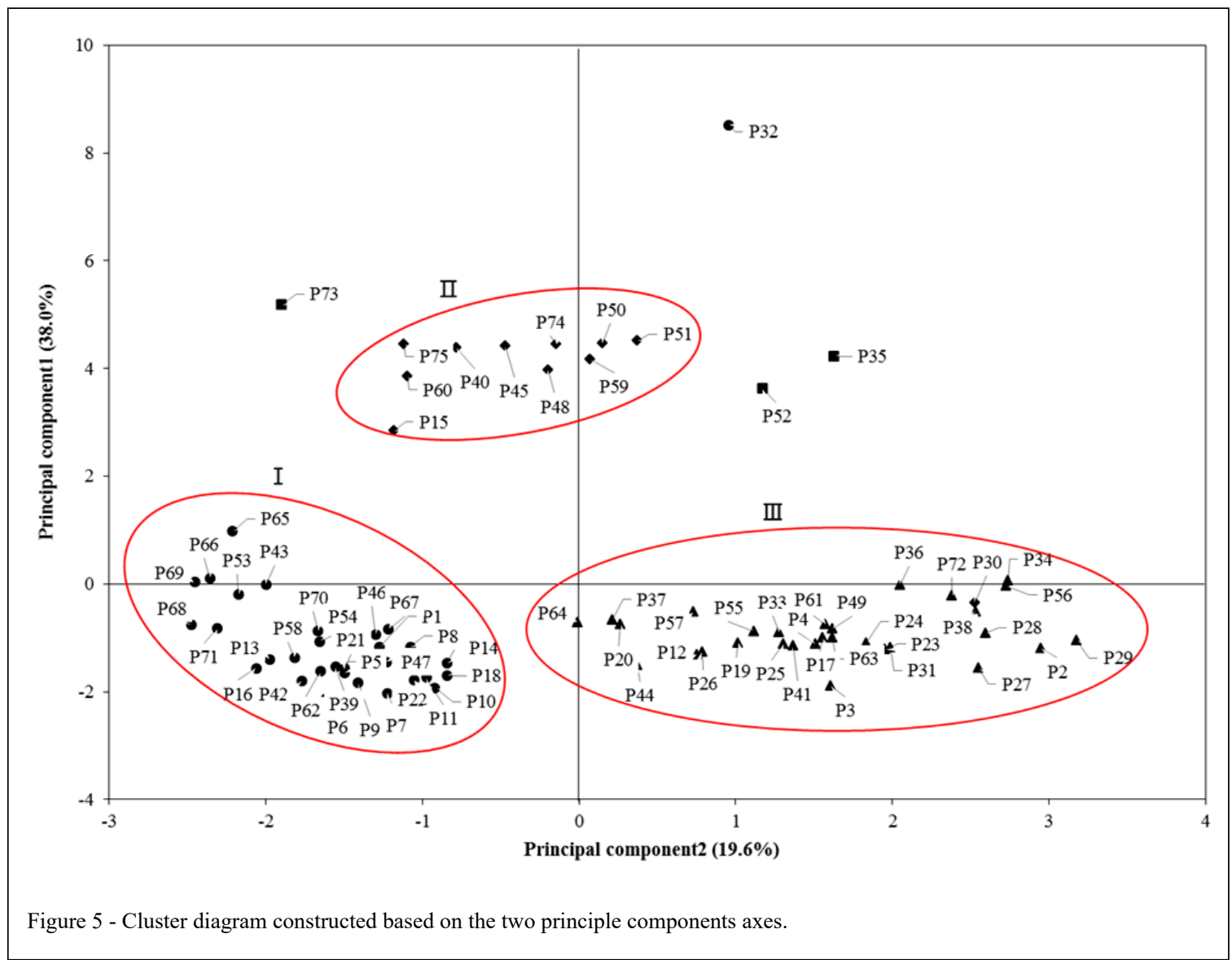

structure and claimed that B ring hydroxylation and glycosylation strongly influenced the antioxidant potential. In our study, sixteen varieties enriched with phenolic contents and high antioxidant activities were screened out. We can concentrate more on identifying the monomer phenols and measuring their contents in potential varieties in the future. Moreover, we can also explore the chemical structure and synthesis of phenols to better understand the mechanism.

In addition, XU \& CHANG (2007) reported that dark-colored beans, specifically black soybeans, had markedly higher phenolic contents and antioxidant activities than did pale-colored legumes. SHEM-TOV et al. (2012) reported that dark, yellow and high-color-intensity chickpea seeds contained more TPC, TFC and FRAP than did light-colored seeds. Moreover, a strong correlation was reported among peanut skin color parameters, TPC and antioxidant activity (CHUKWUMAH et al., 2009). Red and black sword beans had a higher phenolic content and antioxidant capacity than did white sword beans (GAN et al., 2016). Similar results were reported in our study. We found that TPC, TFC, ABTS and FRAP had significant negative correlations with $L^{*}$ and $b^{*}$, which indicated that dark (brown, brown with stripes or spots, purple-dark) pea seeds may have potential health benefits and contain more TPC, TFC, ABTS and FRAP than light-colored seeds, which may be due to the dark seeds being associated with higher levels of tannins (GRELA et al., 2012). We can initially evaluate the color of a seed to judge its phenolic contents antioxidant properties. It is important to legume breeders to have an easy-to-use marker for functional food-related qualities.

The PCA results agreed with those of the cluster analysis. Varieties with high and low TPC, TFC, ABTS and FRAP were classified into separate groups. Some of the germplasm resources that derived from the same region were distributed in different groups, indicating that the clustering results were not significantly related to the geographical origin of the 


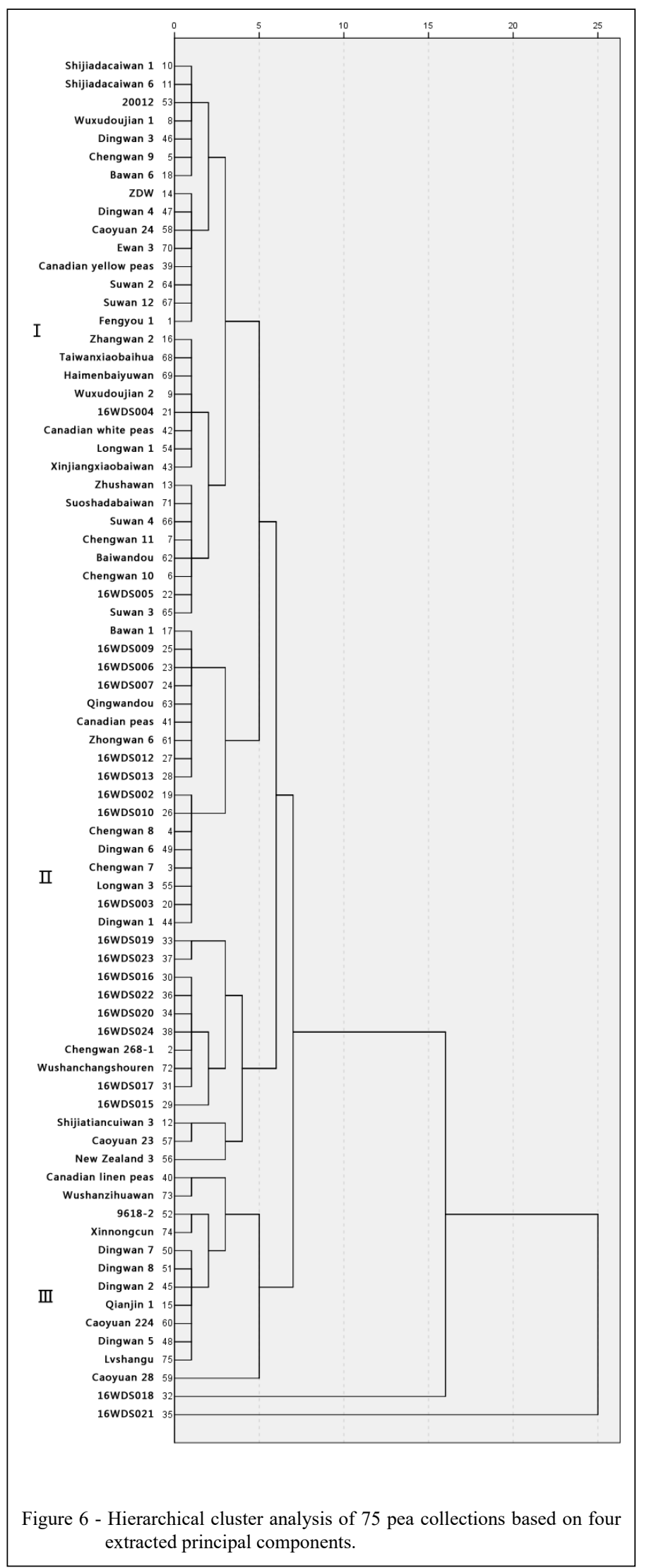

Ciência Rural, v.50, n.5, 2020. 
germplasm, which was in agreement with findings obtained in peas by KENENI et al. (2005) and ANNICCHIARICO et al. (2017). These differences may be caused by accelerated communication between germplasm resources.

In the future, the genetic diversity of pea cultivars can be studied at the molecular level by means of molecular morphological markers, which can play an important role in improving pea germplasm resources. At the same time, analyses can be conducted to develop functional products that benefit human health in terms of the phenolic composition of pea seeds and the molecular mechanisms related to antioxidant activity. By improving the utilization of pea seeds as a functional food and new dietary raw material, as well as their antioxidant activity and other beneficial traits, the present findings can provide a theoretical basis for improving pea breeding.

\section{CONCLUSION}

The pea collection had rich genetic diversity and wide phenols contents. Sixteen varieties enriched with phenolic contents and high antioxidant activities were screened out. 16WDS021 had the highest TFC. TPC, TFC, antioxidant activity and chroma values, which were significantly related: the higher the phenolic contents were, the stronger the antioxidant activity. Dark pea seeds may have potential health benefits and contain more TPC, TFC, ABTS and FRAP than light-colored seeds.

\section{ACKNOWLEDGEMENTS}

The authors sincerely thank the Earmarked Fund for China Agriculture Research System (CARS-08) for financial support. We also appreciate the 12 Academies of Agriculture Sciences and two companies for providing valuable pea varieties.

\section{DECLARATION OF CONFLICT OF INTERESTS}

The authors declare no conflict of interest. The funding sponsors had no role in the design of the study; in the collection, analyses, or interpretation of data; in the writing of the manuscript, and in the decision to publish the results.

\section{AUTHORS' CONTRIBUTIONS}

YFK and TYZ conceived and designed experiments. TYZ, YQ and LYW performed the experiments, TYZ carried out the lab analyses. TYZ and WJS performed statistical analyses of experimental data. TYZ prepared the draft of the manuscript. All authors critically revised the manuscript and approved of the final version.

\section{REFERENCES}

AGOSTINIC-COSTA, T. D. S., et al. Total phenolics, flavonoids, tannins and antioxidant activity of lima beans conserved in a Brazilian genebank. Ciência Rural, v.45, p.335-341, 2015. Available from: <http://www.scielo.br/scielo.php?pid=S010384782014005040030\&script $=$ sci_arttext $>$. Accessed: Oct. 21, 2017. doi: $10.1590 / 0103-8478 \mathrm{cr} 20140030$

AIL-SHTAYEH, M. S., et al. Morphological characterization of snake melon (Cucumis melo var. flexuosus) populations from Palestine. Genetic Resources and Crop Evolution, v.62, p.7-22, 2017. Available from: $<$ https://link.springer.com/article/10.1007\% 2Fs10722-015-0329-0>. Accessed: Oct. 21, 2017. doi: 10.1007/ s10722-015-0329-0.

AMAROWICZ, R., et al. Antioxidant activity of condensed tannins of beach pea, canola hulls, evening primrose, and faba bean. Journal of Food Lipids, v.7, p.195-205, 2007. Available from: <https:// onlinelibrary.wiley.com/doi/abs/10.1111/j.1745-4522.2000. tb00171.x>. Accessed: Oct. 21, 2017. doi: 10.1111/j.17454522.2000.tb00171.x.

AMAROWICZ, R., et al. Free-radical scavenging capacity and antioxidant activity of selected plant species from the Canadian prairies. Food Chemistry, v.84, p.551-562, 2004. Available from: $\quad<$ https://www.sciencedirect.com/science/article/pii/ S0308814603002784>. Accessed: Oct. 21, 2017. doi: 10.1016/ S0308-8146(03)00278-4.

ANNICCHIARICO, P., et al. Diversity in a pea (Pisum sativum) world collection for key agronomic traits in a rain-fed environment of southern Europe. Euphytica, p.213:245, 2017. Available from: <https://link.springer.com/ article/10.1007\%2Fs10681-017-2033-y>. Accessed: Oct. 21, 2017. doi: $10.1007 /$ s10681-017-2033-y.

BAI, Y., et al. Comparison of phenolic compounds, antioxidant and antidiabetic activities between selected edible beans and their different growth periods leaves. Journal of Functional Foods, v.35, p.694-702, 2017. Available from: <https://www.sciencedirect. com/science/article/pii/S1756464617303535?via\%3Dihub>. Accessed: Oct. 21, 2017. doi: 10.1016/j.jff.2017.06.036.

CHUKWUMAH, Y., et al. Peanut skin color: A biomarker for total polyphenolic content and antioxidative capacities of peanut cultivars. International Journal of Molecular Sciences, v.10, p.4941-4952, 2009. Available from: <http:// www.oalib.com/paper/155916>. Accessed: Oct. 21, 2017. doi: 10.3390/ijms10114941.

DEAN, R. E., et al. Genetic redundancy and diversity among 'orange' accession in the U.S. national sorghum collection as assessed with simple sequence repeat (SSR) markers. Crop Science, v.39, p.1215-1221, 1999. Available from: <https://dl.sciencesocieties.org/ publications/ cs/abstracts/39/4/CS0390 041215>. Accessed: Oct. 21, 2017. doi: 10.2135/cropsci1999.0011183X003900040043x.

DECKER, E. A. Phenolics: prooxidants or antioxidants? Nutrition Reviews, v.55, p.396-398, 1997. Available from: $<$ https://academic. oup.com/nutritionreviews/article/55/11/396/1831637>. Accessed: Oct. 21, 2017. doi: 10.1111/j.1753-4887.1997.tb01580.x.

DUEÑAS, M., et al. Assessment of in vitro antioxidant capacity of the seed coat and the cotyledon of legumes in relation to 
their phenolic contents. Food Chemistry, v.98, p.95-103, 2006. Available from: <https://www.sciencedirect.com/science/ article/pii/S0308814605004723>. Accessed: Oct. 21, 2017. doi: /10.1016/j.foodchem.2005.05.052.

DUEÑAS, M., et al. Effect of germination and elicitation on phenolic composition and bioactivity of kidney beans. Food Research International, v.70, p.55-63, 2015. Available from: <https://www.sciencedirect. com/science/article/pii/ S0963996915000332>. Accessed: Oct. 21, 2017. doi: 10.1016/j. foodres.2015.01. 018 .

FERRERES, F., et al. HPLC-DAD-ESI/MS ${ }^{\mathrm{n}}$ profiling of phenolic compounds from Lathyrus cicera L. seeds. Food Chemistry, v.214, p.678-685, 2017. Available from: <https://www.sciencedirect.com/ science/article/pii/S0308814616311621?via\%3Dihub>. Accessed: Oct. 21, 2017. doi: 10.1016/j.foodchem. 2016.07.129.

GAN, R. Y., et al. Sword bean (Canavalia gladiata) as a source of antioxidant phenolics. International Journal of Food Science and Technology, v.51, p.156-162, 2016. Available from: <https:// onlinelibrary. wiley.com/doi/full/10.1111/ijfs.12979>. Accessed: Oct. 21, 2017. doi: 10.1111/ijfs. 12979.

GEIL, P. B.; ANDERSON, J. W. Nutrition and health implications of dry beans: A review. Journal of American College of Nutrition, v.13, p.549-558, 1994. Available from: <https://www.tandfonline. com/doi /abs/10.1080/07315724.1994.10718446>. Accessed: Oct. 21, 2017. doi: 10.1080/07315724.1994. 10718446.

GHARRAS, H. E. Polyphenols: food sources, properties and applications-a review. International Journal of Food Science and Technology, v.44, p.2512-2518, 2009. Available from: <https:// onlinelibrary.wiley.com/doi/pdf/10.1111/j.1365-2621.2009.02077.x>. Accessed: Oct. 21, 2017. doi: 10.1111/j.1365-2621. 2009. 02077.x.

GRELA, E. R., et al. Variability of phenotypic and morphological characteristics of some Lathyrus sativus L. and Lathyrus cicera L. accessions and nutritional traits of their seeds. Genetic Resources and Crop Evolution, v.59, p.1687-1703, 2012. Available from: $<$ https://link.springer.com/article/10.1007/s10722-011-9791-5>. Accessed: Oct. 21, 2017. doi: 10.1007/s10722-011-9791-5.

HAGEBLAD, J., et al. Genetic diversity in local cultivars of garden pea (Pisum sativum L.) conserved 'on farm' and in historical collections. Genetic Resources and Crop Evolution, v.61, p.413-422, 2014. Available from: <https://link.springer.com/ article/10.1007/s10722-013-0046-5>. Accessed: Oct. 21, 2017. doi: $10.1007 / \mathrm{s} 10722-013-0046-5$.

HOECK, J. A., et al. Influence of genotype and environment on isoflavone contents of soybean. Crop Science, v.40, p.48-51, 2000 Available from: $<$ https://dl.sciencesocieties.org/publications/ cs/abstracts/40/1/48>. Accessed: Oct. 21, 2017. doi: 10.2135/ cropsci2000.40148x.

HUNG, P. V. Phenolic compounds of cereals and their antioxidant capacity. Critical Reviews in Food Science and Nutrition, v.56, p.25-35, 2016. Available from: <https://www.tandfonline.com/doi/ full/10.1080/10408398.2012.708909>. Accessed: Oct. 21, 2017. doi: $10.1080 / 10408398.2012 .708909$.

KENENI, G., et al. Extent and pattern of genetic diversity for morpho-agronomic traits in Ethiopian highland pulse landraces I . Field pea (Pisum sativum L.). Genetic Resources and Crop Evolution, v.52, p.539-549, 2005. Available from: <https://link.
springer.com/article/10.1007\%2Fs10722-003-6016-6? LI= true $>$. Accessed: Oct. 21, 2017. doi: 10.1007/s10722-003-6016-6.

KIM, E. H., et al. Comparison of isoflavones and anthocyanins in soybean [Glycine $\max (\mathrm{L}$.) Merrill] seeds of different planting dates. Journal of Agriculture and Food Chemistry, v.60, p.10196-10202, 2012. Available from: <https://pubs.acs.org. ccindex.cn/doi/10.1021/jf3031259>. Accessed: Oct. 21, 2017. doi: $10.1021 / \mathrm{jf3} 031259$

KING, A.; YOUNG, G. Characteristics and occurrence of phenolic phytochemicals. Journal of American Dietetic Association, v.99, p.213-218, 1999. Available from: $<$ https://www.sciencedirect.com/ science/article/pii/S0002822399000516?via\%3Dihub>. Accessed: Oct. 21, 2017. doi: 10.1016/S0002-8223(99) 00051-6.

LEONARDO, C. C.; DORÉ, S. Dietary flavonoids are neuroprotective through Nrf2-coordinated induction of endogenous cytoprotective proteins. Nutritional Neuroscience, v.14, p.226236, 2011. Available from: <https://www.ncbi.nlm.nih.gov/pmc/ articles/PMC3443635/pdf/nihms-381774.pdf $>$. Accessed: Oct. 21, 2017. doi: 10.1179/1476830511Y.0000000013.

LI, L., et al. Food legume production in China, The Crop Journal, v.5, p.115-126, 2017. Available from: <https://www.tandfonline. com/doi/full/10.1179/1476830511Y.0000000013>. Accessed: Oct. 21, 2017. doi: org/10.1016/j.cj.2016.06.001.

LIU, H.K. et al. The influence of light-emitting diodes on the phenolic compounds and antioxidant activities in pea sprouts. Journal of Functional Foods, v.25, p.459-465, 2016.Available from: $<$ https://www. sciencedirect.com/science/ article/pii/S175646461

6301712?via\%3Dihub>. Accessed: Oct. 2017. doi: 10.1016/j. jff.2016.06.028.

MARTÍNEZ, I. B., et al. Morphological characterization of traditional cacao (Theobromacacao L.) plants in Cuba. Genetic Resources and Crop Evolution, v.64, p.73-99, 2017. Available from: $<$ https://link. springer.com/article/10.1007\%2Fs10722-015-0333-4>. Accessed: Oct. 21, 2017. doi: 10.1007/s10722-015-0333-4.

MEENU, M., et al. A rapid high-performance liquid chromatography photodiode array detection method to determine phenolic compounds in mung bean (Vigna radiata L.). International Journal of Food Properties, v.19, p.2223-2237, 2016. Available from: <https://www.tandfonline.com/doi/pdf/1 0.1080/10942912.2015.1121396?needAccess $=$ true $>$. Accessed: Oct. 21, 2017. doi: 10.1080/10942912.2015.1121396.

MESSINA, M. J. Legume and soybeans: overview of their nutritional profiles and health effects. The American Journal of Clinical Nutrition, v.70, p.439S-450S, 1999. Available from: <https://www. researchgate.net/publication/12821341_Legumes_and_soybeans_ Overview_of_their_nutritional_profiles_and_health_effects $>$. Accessed: $\bar{O}$ Oct. 21,2017 . doi: $10 . \overline{1093 / a j c n / 70.3 .439 s . ~}$

MÜLLER, L., et al. Comparative antioxidant activities of carotenoids measured by ferric reducing antioxidant power (FRAP), ABTS bleaching assay ( $\alpha$ TEAC), DPPH assay and peroxyl radical scavenging assay. Food Chemistry, v.129, p.139148, 2011. Available from: <https://www.sciencedirect.com/ science/article/pii/S0308814611006108?via\%3Dihub>. Accessed: Oct. 21, 2017. doi: 10.1016/ j.foodchem. 2011.04.045.

OU, B.; HUANG, D. J., et al. Analysis of antioxidant activities of common vegetables employing oxygen radical absorbance 
capacity (ORAC) and ferric reducing antioxidant power (FRAP) assays: A comparative study. Journal of Agriculture and Food Chemistry, v.50, p.3122-3128, 2002. Available from: <https:// pubs.acs.org.ccindex.cn/doi/10.1021/jf0116606>. Accessed: Oct. 21, 2017. doi: 10.1021/jf011660 6 .

PAJAK, P., et al. Phenolic profile and antioxidant activity in selected seeds and sprouts. Food Chemistry, v.143, p.300-306, 2014. Available from: <https://www.sciencedirect.com/science/ article/pii/S030881461300993X?via\%3Dihub>. Accessed: Oct. 21, 2017. doi: 10.1016/j.foodchem.2013.07.064.

PÉREZ-BALIBREA, S., et al. Genotypic effects on the phytochemical quality of seeds and sprouts from commercial broccoli cultivars. Food Chemistry, v.125, p.348-354, 2011. Available from: <https:/www.sciencedirect.com/science/article/ pii/S0308814610010721?via\%3Dihub>. Accessed: Oct. 21, 2017. doi: 10.1016/j.foodchem.2010.09.004.

RANDHIR, R., et al. Phenolics, their antioxidant and antimicrobial activity in dark germinated fenugreek sprouts in response to peptide and phytochemical elicitors. Asia Pacific Journal of Clinical Nutrition, v.13, p.295-307, 2004. Available from: <http:// www.apjcn.org/update/pdf/2004/3/295-307/295.pdf $>$. Accessed: Oct. 21, 2017. doi: 10.1146/annurev.nutr.24.012003.132434.

RAUTER, A. P., et al. Liquid chromatography-diode array detection-electrospray ionization mass spectrometry /nuclear magnetic resonance analyses of the anti-hyperglycemic flavonoid extract of genista tenera structure elucidation of a flavonoid- $C$ glycoside. Journal of Chromatography A, v.1089, p.59-64, 2005. Available from: <https:/www.sciencedirect.com/science/article/ pii/S0021967305012094?via\%3Dihub>. Accessed: Oct. 21, 2017. doi: 10.1016/j.chroma.2005.06.046.

RICE-EVANS, C. A., et al. Structure-Antioxidant activity relationships of flavonoids and phenolic acids. Free Radical Biology Medicine, v.20, p.933-956, 1996. Available from: $<\mathrm{https}$ :/ www.sciencedirect.com/science/article/pii/0891584995022279>. Accessed: Oct. 21, 2017. doi: 10.1016/0891-5849(95)02227-9.

SAHA, U., et al. Near-infrared spectroscopic models for analysis of winter pea (Pisum sativum L.) quality constituents. Journal of the Science of Food and Agriculture, v.98, p.4235-4267, 2018. Available from: <https://onlinelibrary.wiley.com/doi/full/10.1002/ jsfa.8947>. Accessed: Nov. 20, 2018. doi: 10.1002/jsfa.89 47.

SANTOS, R. C., et al. Morphological characterization of leaf, flower, fruit and seed traits among Brazilian Theobroma L. species. Genetic Resources and Crop Evolution, v.59, p.327345, 2012. Available from: <https://link.springer.com/article/1 0.1007\%2Fs10722-011-9685-6>. Accessed: Oct. 21, 2017. doi: $10.1007 / \mathrm{s} 10722-011-9685-6$.

SCALBERT, A., et al. Dietary polyphenols and the prevention of diseases. Critical Reviews in Food Science, v.45, p.287306, 2005. Available from: <http://www.pkdiet.com/pdf/ GrapesPolyphenolics\%20and\%20Health.pdf $>$. Accessed: Oct. 21, 2017. doi: 10.1080/1040869059096.

SEGEV A., et al. Determination of polyphenols, flavonoids, and antioxidant capacity incolored chickpea (Cicer arietinum L.). Journal of Food Science, v.75, p.S115-S119, 2010 Available from: <https://onlinelibrary.wiley.com/doi/pdf/10.11 11/j.1750-3841.2009.01477.x>. Accessed: Oct. 21, 2017. doi: 10.1111/ j.1750-3841.2009.01477.x.
SHEM-TOV, Y., et al. Determination of total polyphenol, flavonoid and anthocyanin contents and antioxidant capacities of skins from peanut (Arachis hypogaea) lines with different skin colors. Journal of Food Biochemistry, v.36, p.301-308, 2012. Available from: $<$ https://onlinelibrary.wiley.com/doi/full/10.11 11/j.1745-4514.2011.00539.x>. Accessed: Oct. 21, 2017. doi: 10.1111/j.1745-4514.2011.0053 9.x.

SUN, X. L., et al. SSR genetic linkage map construction of pea (Pisum sativum L.) based on Chinese native varieties. The Crop Journal, v.2, p.170-174, 2014. Available from: <https://www. sciencedirect.com/science/article/pii/S2214514114000178>. Accessed: Oct. 21, 2017. doi: 10.1016/j.cj.2014.03.004.

THAKUR, B., et al. Diversity analysis of pea genotypes using RAPD markers. Legume Research, v.4, p.196-201, 2018. Available from: <https://arccjournals.com/uploads/Finalattachment-published- LR-3709. pdf>. Accessed: Nov. 20, 2018. doi: 10.18805/LR-3709.

TORRES, J., et al. The impact of heating and soaking on the in vitro enzymatic hydrolysis of protein varies in different species of tropical legumes. Food Chemistry, v.194, p.377-382, 2016. Available from: <https://www.sciencedirect.com/science/article/ pii/S0308814615012054>. Accessed: Oct. 21, 2017. doi: 10.1016/j. foodchem.2015.08.022.

TROSZYńSKA, A.; CISKA, E. Phenolic compounds of seed coats of white and coloured varieties of pea (Pisum sativum L.) and their total antioxidant activity. Czech Journal of Food Science, v.20, p.15-22, 2002. Available from: <https://www.agriculturejournals. cz/publicFiles/50862.pdf $>$. Accessed: Oct. 21, 2017 . doi: 10.17221/3504-CJFS.

UPADHYAYA, H. D., et al. Phenotypic diversity in Cajanus species and identificationof promising sources for agronomic traits and seed protein content. Genetic Resources and Crop Evolution, v.60, p.639-659, 2013. Available from: $<$ https://link. springer.com/article/10.1007\%2Fs10722-012-9864-0>. Accessed: Oct. 21, 2017. doi: 10.1007/s10722-012-9864-0.

VAJDY, M., et al. Immunomodulatory properties of vitamins, flavonoids and plant oil and their potential as vaccine adjuvants and delivery systems. Expert Opinion on Biological Therapy, v.11, p.1501-1513, 2011. Available from: <https:// www.tandfonline.com/doi/abs/10.1517/14712598.2011.62 3695? journalCode $=$ iebt20>. Accessed: Oct. 21, 2017. doi: $10.1517 / 14712598.2011 .623695$.

WAN, S. W., et al. Genetic diversity of agronomic traits in 271 pea germplasm resources. Journal of Plant Genetic Resources, v.18, p.10-18, 2017. (in Chinese) Available from: <http://www. en.cnki.com.cn/Article en/CJFDTotal-ZWYC201701002.htm>. Accessed: Oct. 21, 2017. doi: 10.13430/j.cnki.jpgr.2017.01.002.

WANG, X., et al. Volatile flavor compounds, total polyphenolic contents and antioxidant activities of a China gingko wine. Food Chemistry, v.182, p.41-46, 2015. Available from: $\quad<$ https://www.sciencedirect.com/science/article/pii/ S0308814615003118?via\%3Dihub>. Accessed: Oct. 21, 2017. doi: 10.1016/j.food chem.2015.02.120.

WOOD, J. G., et al. Sirtuin activators mimic caloric restriction and delay ageing in metazoans. Nature, v.430, p.686-689, 2004. Available from: <https://www.nature.com/articles/nature02789>. Accessed: Oct. 21, 2017. doi: 10.1038/nature02789. 
XU, B. J.; CHANG, S. K. C. A comparative study on phenolic profiles and antioxidant activities of legumes as affected by extraction solvents. Journal of Food Science, v.72, p.159-166, 2007. Available from: $<$ https://onlinelibrary.wiley.com/doi/full/10 $.1111 / \mathrm{j} .1750-3841.2006 .00260 . \mathrm{x}>$. Accessed: Oct. 21, 2017. doi: $10.1111 / \mathrm{j} .1750-3841.2006 .00260 . x$.

XU, B. J.; CHANG S. K. C. Total phenolic, phenolic acid, anthocyanin, flavan-3-ol, and flavonol profiles and antioxidant properties of pinto and black beans (Phaseolus vulgaris L.) as affected by thermal processing. Journal of Agriculture and Food Chemistry, v.57, p.4754-4764, 2009. Available from: <https://pubs.acs.org.ccindex.cn/ doi/abs/10.1021/jf900695s >. Accessed: Oct. 21, 2017. doi: $10.1021 / \mathrm{jf} 900695 \mathrm{~s}$.

XU, B. J., et al. Comparative analyses of phenolic composition, antioxidant capacity, and color of cool season legumes and other selected food legumes. Journal of Food Science, v.72, p. 167-177, 2007. Available from: $<$ https://onlinelibrary.wiley.com/doi/full/10 $.1111 / \mathrm{j} .1750-3841.2006 .00261 . \mathrm{x}>$. Accessed: Oct. 21, 2017. doi: $10.1111 / \mathrm{j} .1750-3841.2006 .00261 . \mathrm{x}$.

$\mathrm{XU}, \mathrm{F}$, et al. Effect of blue light treatment on fruit quality, antioxidant enzymes and radical-scavenging activity in strawberry fruit. Scientia Horticulturae, v.175, p.181-186, 2014. Available from: $\quad<$ https://www.sciencedirect.com/science/article/pii/ S0304423814003288>. Accessed: Oct. 21, 2017. doi: 10.1016/j. scienta.2014.06.012.
YAO, Y., et al. Major phenolic compounds, antioxidant capacity and antidiabetic potential of rice bean (Vigna umbellata L.) in China. International Journal of Molecular Sciences, v.13, p.27072716, 2012. Available from: <https://www.ncbi.nlm.nih.gov/pmc/ articles/PMC3317682/pdf/ijms-13-02707.pdf >. Accessed: Oct. 21, 2017. doi: 10.3390/ijms13032707.

ZADERNOWSKI, R., et al. Phenolic acid profiles in some small berries. Journal of Agriculture and Food Chemistry, v.53, p.2118-2124, 2005. Available from: $<$ https://pubs.acs.org.ccindex. cn/doi/abs/10.1021/jf040411p >. Accessed: Oct. 21, 2017. doi: 10.1021/jf040411p.

ZHAO, Y., et al. In vitro antioxidant activity of extracts from common legumes. Food Chemistry, v.152, p.462-466, 2014. Available from: <https://www.sciencedirect.com/science/article/ pii/S030881461301861X?via\%3Dihub>. Accessed: Oct. 21, 2017. doi: 10.1016/j.foodchem.2013.12.006.

ZHU, F., et al. Anthocyanins, hydroxycinnamic acid derivatives, and antioxidant activity in roots of different Chinese purplefleshed sweetpotato genotypes. Journal of Agricultural and Food Chemistry, v.58, p.7588-7596, 2010. Available from: <https:// pubs.acs.org/doi/pdf/10.1021/jf101867t $>$. Accessed: Oct. 21, 2017. doi: $10.1021 / \mathrm{jf101867t}$.

ZONG, X. X., et al. Descriptors and data standard for pea (Pisum sativum L.). Beijing: China Agricultural Press, 2005. 1820p. (in Chinese). 